\title{
Meyer's Approach on Musical Analysis and Its Relevance to Indonesian Analytical Study of Western Music
}

\author{
Andre Indrawan \\ Music Department, The Faculty of Performing Arts, \\ Institut Seni Indonesia Yogyakarta \\ email: indrawan andre@isi.ac.id
}

\begin{abstract}
This critical review of Leonard Bunce Meyer's musical analysis theory is aimed at obtaining a basic understanding of an approach that seems uncommon in Indonesian studies of Western music. This study uses a speculative method with descriptive as well as critical approaches, where Meyer's analysis theory is depicted critically by conforming it toward Nicolas Cook's critical review which was based on the Shenkerian concept. The relevance application of this analysis model in the studies of musical form in Indonesia then is discussed. This study concluded that the psychological music analysis of Meyer was carried out by the foreground expectations of the tonal music linear and rhythmical analysis. Compared to the Shenkerian approach which gives greater attention to the harmonic reduction that focused on the harmonic background of tonal music, Meyer's approach would be less practical in observing at large-scale musical structures. Meyer's analysis would be valuable to the performers as well as music analysts if they also take into account their musical style concepts which mostly regarded as the area of aesthetic rather than technical analysis. For Indonesia, this method is appropriate for Master and Doctorate studies in Western Music.
\end{abstract}

Keywords: Meyer, music, analysis, tonal.

\begin{abstract}
ABSTRAK
Ulasan kritis teori analisis musikal Leonard Bunce Meyer ini bertujuan untuk memperoleh pemahaman dasar tentang pendekatan yang tampaknya tidak biasa dalam studi musik Barat di Indonesia. Penelitian ini menggunakan metode spekulatif dengan pendekatan deskriptif serta kritis dengan menggambarkan teori analisis Meyer melalui tinjauan kritis Nicolas Cook yang didasarkan pada konsep Shenker. Untuk selanjutnya relevansinya terhadap penerapan studi bentuk musik di Indonesia didiskusikan. Studi ini menyimpulkan bahwa analisis musik psikologis Meyer dilakukan oleh ekspektasi permukaan dari analisis linear dan ritmis musik tonal. Dibandingkan dengan pendekatan Shenkerian yang lebih memperhatikan reduksi harmonik yang berfokus pada latar belakang harmonik dari musik tonal, pendekatan Meyer akan kurang praktis dalam mengamati struktur musik skala besar. Analisis Meyer akan bermanfaat bagi para penyaji serta analis musik jika mereka juga memperhitungkan konsep gaya musik mereka yang sebagian besar dianggap sebagai bidang estetika daripada analisis teknis. Di Indonesia metode ini sesuai untuk studi tingkat Magister dan Doktor dalam Musik Barat.
\end{abstract}

Kata kunci: Meyer, musik, analisis, tonal. 


\section{INTRODUCTION}

This study discusses a critical review of Leonard Bunce Meyer's (1918-2007) psychological analysis, which is one of the many approaches in tonal music analysis. Meyer had contributed very much to the development of music aesthetic theory and analysis of musical composition fields (see Sparshott \& Cumming, 2018) Research in Music Psychology encompasses understanding psychological processes in music listening, playing, and writing a composition, by using empirical, theoretical and computational methods (see Music, 2019). Meyer's theory was written in his masterpiece, the Emotion and Meaning in Music (1956), which combines Gestalt theory and the Pragmatic theories of Peirce and John Dewey, which tries to explain the existence of emotions in music (Geyer, 2011; Shattuck, 2008).

This analysis model is necessary to be applied in the Indonesian study on Western music. For Indonesian music students who up to date have only studied analytical techniques from the only musical form analysis approach, Meyer's theory analysis is very important to be appreciated in order to broaden their horizons. Except for the only article written by Indrawan (2010) that wrote Meyer's method, Indonesian scientific journal articles that discuss research on music analysis were still not easy to be found. However, Indrawan's (2010) work did not provide sufficient background, method, and supporting sources. In this article besides these deficiencies are filled with new data, the discussion is also contextualized with its relevance in the Indonesian analytical study of Western music.

Currently, few Indonesian researchers interested to utilize musical form analysis approach in their study. Among others are, Lamba, Ardini, Darmayuda, and Sumerjana (2019), which revealed the musical form of the Torajan folk songs that had been arranged by a pop band. Other musical forms analyses were conducted by Syahrian, Irawan, and Aryanto (2019) which analyzed the musical form applied in the Ida Sang Sujati, a Balinese song written by Darmayuda, that was sung during the Bali Kumara singers' performance in 2016. In addition interest in contemporary composition was also exists among Indonesian students. Among them was Putra (2019) who studied the musical form of a new composition. However, there was a slightly out of what most Indonesian analysts did, Aulia dan Indrawan (2019) did not analyze tonal music but the atonal system. Their study was not concerning musical form but on the application of a certain serial musical system that was applied on a 
Brindle's (1917-2003) work (Brindle, 1963, 1982)

Internationally, studies that allude to the role of Leonard Meyer in analysis music were also not easy to find. Among these writings, it was from McCarthy \& Globe (2002) that did not discuss his analytical theories but his position as one of the contributors in the establishment of philosophical concepts of music education. However, Meyer himself revealed his concepts of musical analysis in several journals. One of his thinking written in a journal published by the American Society for Aesthetic. Although it was associated with many topics, it is mostly related to music analysis. (Meyer, 1957). The loyalty of his expertise to music analysis seems to be greater than to the field of aesthetics, this can be seen from the many articles on music topics that were written in the years before his death. (Meyer, 1982, 1983, 1998).

Due to the very limited availability of writings on Western tonal music analysis, and that especially critically examine the concepts of Meyer's analysis, as well as discussions that directly refer to the examples of his analysis, research needs to be done. Problems formulated in this study are: (1) Who is Leonard B. Meyer and what are his works that correspond to music analysis? (2) What are the strengths as well as weaknesses of Meyer's Analytical Method? (3) How important is if Meyer's analytical method being studied in the Indonesian Studies on Western Music?

The aim of this study is to gain a basic understanding of the analytical approach that seems to be uncommon in the study of Western music in Indonesia that most of which use the musical form analysis. In addition, this study will be useful to Indonesian music analysts, especially those who engage with tertiary institutions who offer Western music studies as new information related to a different model in music studies. Appreciation of this music analysis figure will at least inspire Indonesian Western music analysts that there are actually various approaches can be utilized in conducting analytical music studies. By knowing the strength and weaknesses of this method, there will be more choices for the analysts to use any analytical techniques that are more suitable for certain material to be analyzed.

After the methodological approach section, the discussion on Meyer's method of analysis will be initialized by his biographical notes and then continued by an overview of his major works that were discussed by other theorists. In the next step, Meyer's music analysis method, a practical example of his linear and rhythmical 
analysis, and finally a critique of Meyer's analysis method, will be discussed. Finally, this paper will be concluded with my general comment about Meyer's theory and its appropriateness to be used in Indonesian studies on Western Music.

\section{RESEARCH METHODS}

This inquiry his musical analysis method this study uses a speculative method with utilizes approaches, such as a critical as well as a descriptive. This method is hardly applied due to its risks leading the researcher to be too subjective if carried away by non-substantial ideas. Nevertheless, since the objective of the speculative method is to formulate a philosophy or theory, then it seems the most appropriate to solve the three problems of this study. Description means fully and systematically describing a subject being study while Critical means evaluating it based on certain judgment criteria. (Watanabe, 1967) The material object of this research is Leonard B. Meyer's musical analysis theory while its formal object is the specification of the techniques he uses in analyzing tonal music. The assessment of technical specifications will be carried out according to the perspective of critical studies with the use of Shenkerian's criteria. This study is done through several steps. First of all, the historical background of the theorist and his major works is revealed through a literature survey. In the next step, basic concepts of Mayer's analysis tools are understood and then a practical example of Meyer's linear and rhythmical analysis is depicted. The example then is critically compared to Nicolas Cook's critical review which was based on the Shenkerian concept on Meyer's theory.

\section{DISCUSSION}

\section{Historical Background}

Since the Renaissance era, in about the 14th and 15th AD, up to the almost the entire part of the nineteenth century, in the history of Western art music, the trend of the change of musical form and style within tonal patterns had been interactively influenced by the innovation in music theories, practices, and creativities. As a result, musical system development has indeed reached its maximum achievement. However, the systematically changes in each of the historical eras were happened around the same system, the tonal, that based on the tonic dominant framework within the diatonic scale. This tonal pattern was, in fact, a 
contrasting reaction to the modal scale system that utilized during the Medieval era, which was practiced before the Renaissance (Cope, 1984; Indrawan, 2019).

After experiencing development processes that took the time of centuries, the tonal tendency was finally replaced by the new system, the "atonal." At the beginning of the next following twentieth-century Modern era, there was a movement where some major composers tried to against those tonal patterns. During that time developed a musical system that was based not on a tonal but an atonal pattern. It seems that the Modern period in musical history was not only exited as a reaction to the Romantic period, but essentially to all preceding periods, and more obvious to the tonal system (Cope, 1984: 1-30). It is interesting that during the first half of the $20^{\text {th }}$ century, while music met its new direction, tonal music was being a musical analysis target. Various approaches have been applied to analyzing tonal music (Bent, 1980, 1987). Meyer is one among music theorists and analysts who use a psychological approach in his study.

\section{Biography of Leonard Bunce Meyer}

Meyer who was born in New York, in 1918 is known as an American musicologist and aesthetician. In 1948 he received his MA in music and philosophy, from Columbia University, and six years later he received his Ph.D. in the history of culture, from the University of Chicago. From 1961 until 1970 he was a professor and chairman of the Department of Music at that university. Five years after that he became a professor of music and humanity at the University of Pennsylvania (Sparshott \& Cumming, 2018).

The overview of Meyer's major works is given by almost all recent music theorists, that can be obtained from some books about music analysis. According to the historical account of the 20th-century music analysis, Meyer is classified as one of the other analysts of the period 1945-60 whose concern with the linguistics, cybernetics and thematic unity issues. From some of his works that having a relationship with the music analysis and aesthetic, the Emotion and Meaning in Music (Meyer, 1956) which mostly cited by other music theorists for their works, is the best known (Bent, 1980, and 1987: 57). In this book, he developed Shenker's dynamic view of musical importance in psychological terms. He mentions the information theory of musical style that music conditioning the systems of 
expectations and musical meaning (Sparshott \& Cumming, 2018).

Other similar comments, which were given by Lewin (1981) and Fubini \& Hatwell (1990) are discussed specifically in the context of theory and the development of music aesthetic. Lewin (1981: 133) comments that to construct an ambitious theory of emotion and meaning in music, Meyer approaches grammatical considerations of musical structure by using the notion of expectation and uncertainty. In discussing the twentieth-century music aesthetic formalism, Fubini \& Hatwell (1990) considers Meyer as an example of the psychologist's concern in the music aesthetic theory development. His contribution to the music aesthetic theory is his main concern with the meaning of music, which discussed how the meaning is communicated. By combining Gestalt psychology and information theory, Meyer is not only examined musical structure but also the emotional reaction of its audience (Fubini \& Hatwell, 1990: 387).

Meyer's information theory is reformulated in his other work, Music, the Arts, and Ideas: Patterns and Predictions in Twentieth-Century Cultures (Meyer, 1967). It is reformulated in terms of mathematical and predicts that musical arts from different world-views will exist without joining in pluralistic civilization. In the Explaining Music: Essay and Exploration (Meyer, 1973) he investigates the principal structure of tonal music with its relationship to the criticism.

\section{Meyer's Music Analysis Method}

The review of Meyer's psychological approach to musical analysis is clearly mentioned by Nicholas Cook in A Guide to Musical Analysis (Cook, 1987) His critical review of Meyer's approach is mostly based on Meyer's Emotion and Meaning in Music. According to Cook, Meyer sees music as a pattern. In the book that based on various psychological theories that were current in the 1950s, Meyer wrote a theory that the frustration of expectations, which in the psychological term is called the inhibition of a tendency to respond, resulting in musical emotion on its listener. The expectations determined by two things: (1) competent listener interprets what he hears because he knows what to expect, and (2) by the musical patterns that are interpreted, which are called close and open. Cook's opinion about this is, that Meyer tends to talk about what implies in music rather than what is expected by the listener; or in other cases talked about how the competent listener responds to music (Cook, 
1987: 70).

The psychological approach in the musical analysis is applicable to any kind of music because the concept of openness and closure are not tied to a single style. He called the 'style analysis' for his method in studying this approach. Cook quotes Meyer's statement that the emotional content of a certain musical structure can be explained only if we have enough knowledge about stylistic norms (Meyer, 1989). Consequences of Meyer's statement are: (1) Meyer restricts himself to the experience of unity and coherence in music and (2) to the analysis of tonal music (Cook, 1987: 71).

Meyer's approach to rhythm analysis that is complementary to his approach to pitch based on his principles of patterning. The rhythmical patterns constructed by a combination of a downbeat and one or two upbeats are classified into five types: iamb (up-down), anapest (up-down-down), trochee (down-up), dactyl (down-up-up) and amphibrach (up-down-up). As shown in figure 1 the minus symbol (" - ") is used to indicate a downbeat and a downward slur $(\cup)$ for upbeat. A symbol comprises a combination of a downbeat sign above an upbeat sign (the $\checkmark$ ), which means that at first, it seems to have an accent, but then considered as unaccented. When an upbeat is placed above a downbeat sign (the $\smile$ ), it means the opposite (Cook, 1987: 78).

\section{Iamb: \\ Anapest: \\ Trochee: \\ Dactyl: Amphibrach:}

\section{Figure 1:}

Five basic rhythmic patterns in Meyer's analysis.

These patterns are used analogously to his pitch analysis. An incomplete rhythmic group implies continuation while a complete one implies closure hierarchically. The rhythmic analysis steps begin with the complex details up to the simple one where finally the whole system of music is based on the rhythmic group comprises down and upbeats. 


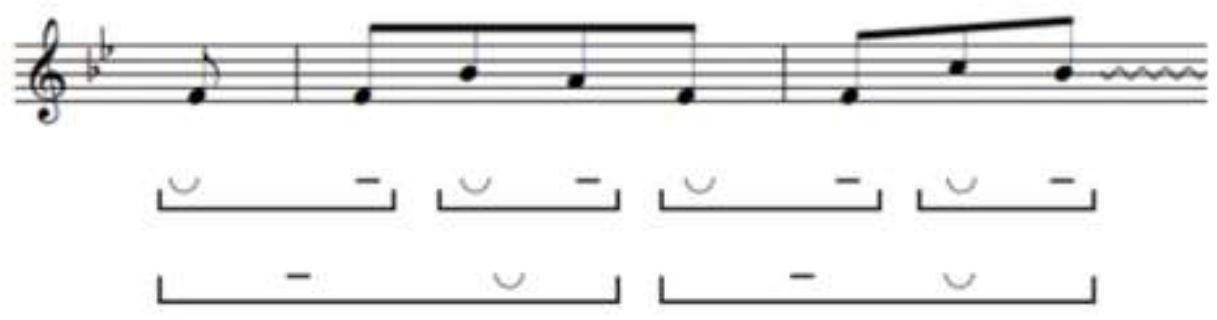

Figure 2:

The first two-level rhythmical analyses.

The first two steps of this rhythmic analysis are the most important ones in Meyer's analysis. In the first step, downbeats have to be determined and then decide how the upbeats are associated with them to form groups of successive levels (Cook, 1987: 77). As the first practical example in clarifying his method, Meyer uses Schubert's work, Das Wanderen.

\section{Practical Example of Meyer's Linear and Rhythmical Analysis}

Compared to of Shenkerian method of analysis, there is a similarity that both consist of reduction which is aligned by the original and used beams, to group several notes into a pattern. The differences are in the function of their beaming systems. The beam of Shenkerian chart is used for constituting a single structural motion, while Meyer's chart is not only for the same purpose but also to mention a kind of expectation.

He divides the beam into two groups with an arrowhead symbol to describe a group of expectations and its continuation. He considers a leap interval before the appearance of the descending scale, which he called it as a gap-fill motion. Related to this case, Meyer explains that: "a disjunct interval may be understood as a kind of incompleteness - a gap - which implies that the notes skipped over will be presented in what follows." The gap and its implied note are called generative event which implying its continuation (Meyer, 1973: 144).

Other gap-fill motions in the example are prolonged or delayed so that the implied motion does not directly upon the generative event. Another case of the delayed implied motion also involves the relationship between pitch patterns and rhythmic patterns which contradict between each other where the second closed 
earlier than the first which delays the closure and resulting in an emptiness in the next following bar.

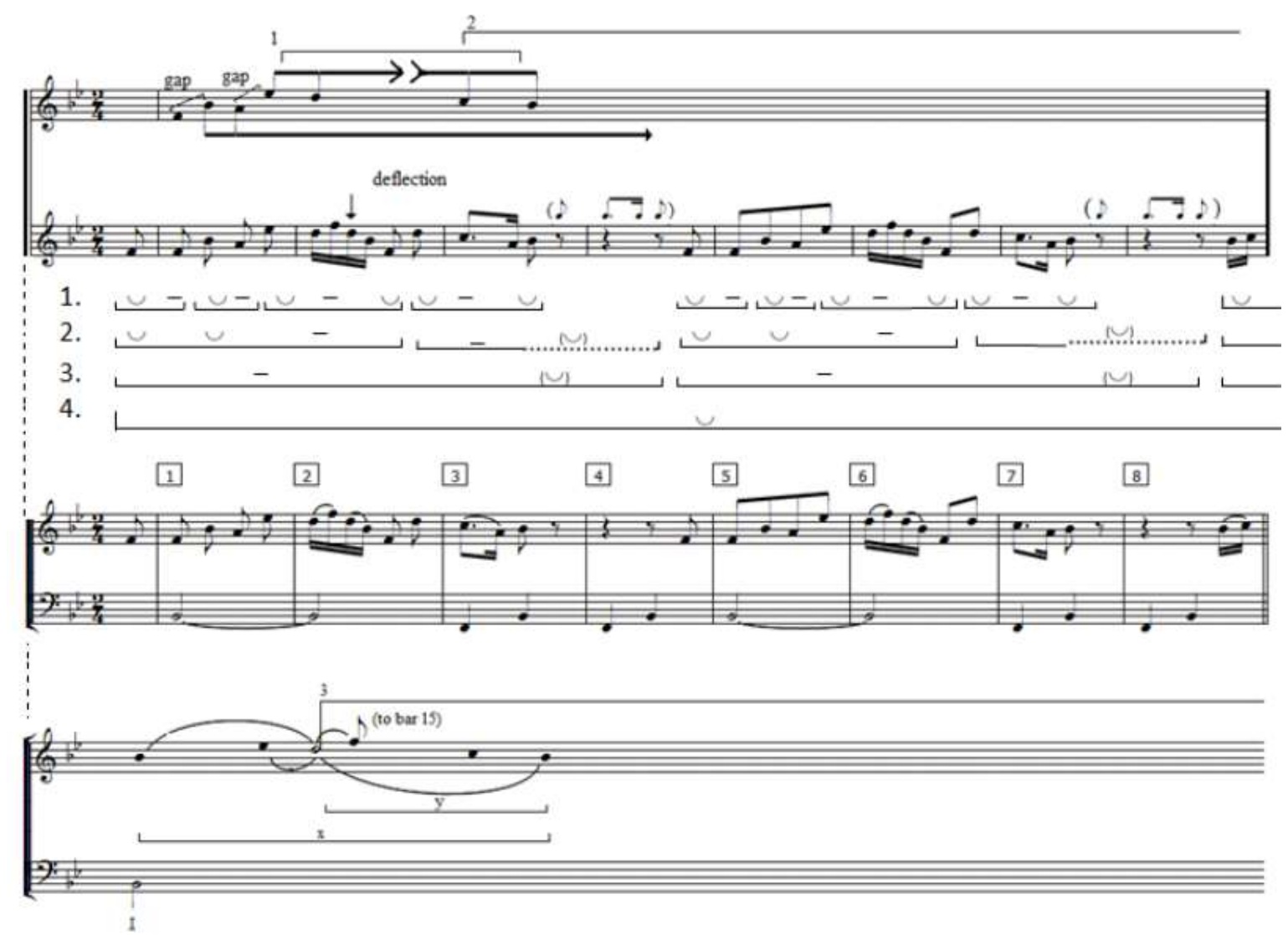

Figure 3:

Meyer's analysis on Schubert's Das Wanderen (Bent, 1987; Cook, 1987: 70).

Meyer divides his rhythmical analysis into at least two levels. On the analysis of Schubert's Das Wanderen, he started the first level at the start of the first bar excluding the introduction. He did not start with an introduction because it has already got a clear rhythmic structure where other musical aspects are not active. F, A, D of bars 1-2 are accented because of the melodic structure. The appearance of $B$ flat before $A$ as the neighboring note separates both notes from what came before and after them. A similar case happened with $E$ flat that appears before $D$ but then continued up to $\mathrm{F}$ as another member of the group. This because $\mathrm{D}$ is prolonged by an arpeggio that completed by $\mathrm{F}$. In level 2 each group of the $1^{\text {st }}$ level corresponds to a beat as it explained by Cook that: "...each group at the second level must start and end coincidentally with some group at first level rather than halfway through them." (Cook, 1987: 78). 


\section{Critique of Meyer's Analysis Method}

Meyer's method is strongly criticized by Cook (1987) that Meyer's rhythmic analysis method is successful as a means of observing music but not as a means of explaining music. The rhythmic analysis is less useful in observing at a large-scale structure than a more detailed level. That is due to the accentuation nature changes between foreground and background levels. He strengthens his critic with the statement that the analytical emphasis has to be not on what the large scales rhythmic structure is but on how it is realized in a given instance (Cook, 1987: 8081).

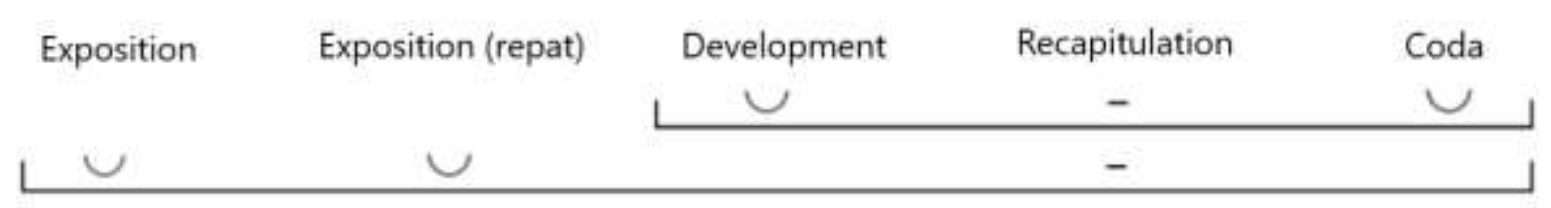

Figure 4:

Meyer's rhythmic analysis pattern of a large-scale structure.

As Cook (1987) comments on it, Meyer considers a piece as a single event in the form of prolongation of tonic harmony with the third in the soprano voice (Cook, 1987: 80). Because accurate musical observations are manifested in the harmonic structure as the key, it will produce a simpler analysis than Meyer's interpretation which is more abstract than linear and rhythmic patterns. Compared to Meyer's concept, Shenkerian reduction actually clarifies the harmonic continuity but suppresses the foreground contrast. Meyer's technique is obviously useful for analyzing surface layer and rhythmic contrasts. However, it is less useful for generalization and explanation in music analysis. Consequently, his technique is a good starting point in music analysis because it is clarifying the obvious thing about music. In contrast, analysis is aimed at explaining music; that is to advance from obvious to the non-obvious. He suggests that for music performance, Shenkerian technique is more helpful in refining interpretation because the difficulty lies not merely in projecting foreground contrasts, but also in achieving some kinds of background continuity (Cook, 1987: 80, 87-89). 


\section{Contextualizing with Indonesian Western Music Studies}

The analysis of musical form is one among compulsory subjects taught in music study programs at Indonesian higher arts education. Even though music study programs, especially, the musical arts and music education, is up to date still focused on musical form analysis it has passed quite long historical steps to achieve a wider scope in its approaches. Current musical form analysis in Indonesian curriculum was initially introduced by R.M.A.P. Suhastjarja, the last director of the Akademi Musik Indonesia Yogyakarta. During that time the subject was taught by Karl-Edmund Prier, a German-Indonesian teaching staff. The subject had been continuously practiced from the initial establishment period of the Academy in 1964 until about the first four years period after it had integrated into the body of Yogyakarta Indonesian Institute of the Arts in 1984. Since 1996 the knowledge has been formulated by Prier (2004) in his book as the IImu Bentuk Musik (The knowledge of Musical Form), which has been considered as the first Indonesian published book for music analysis. The first print was dated to 1996, but it was reprinted as the second edition in 2004. Since 2008 Music Department at ISI Yogyakarta, has made an initial step by changing the name of analysis subject from the IImu Bentuk Musik (the science of musical form), to the IImu Analisis Musik (the knowledge of musical analysis). Under the new name, its subject content of the study would not be limited only to formal analysis so that other approaches could be inserted.

Approaches outside the analysis of musical forms also need to be known by music students in Indonesia as the knowledge that will broaden their perspectives in music analysis studies. Of course it is not only psychological analysis model by Leonard Meyer needs to be learned but also other basic approaches that have already contributed to the current development of music analysis, such as the Shenkerian Analysis (Forte \& Gilbert, 1982) and the Generative Theory of Tonal Music (GTTM) (Lerdhal \& Jackendoff, 1996). However, until 2015 undergraduate music students' understanding of musical forms was still average. Therefore, since 2016 the Music Department has added hours of study for musical forms, from formerly two semesters being four semesters length. In the first two semesters, students are given the introduction to Musical Form Theories then in the next two semesters the practice of Musical Form Analysis. Seeing this reality, it seems that at 
the moment the study of musical analysis outside the musical form analysis, such as Meyers' as well as Shenkerian model would not be appropriate yet for music undergraduate students in Indonesian universities.

\section{CONCLUSION}

In conclusion, first of all, we should basically agree with Cook's critics that Shenkerian analysis is more useful in performance interpretation. The positive one of Meyer's analysis is his application of the psychological approach that will be helpful to realize the appearance of natural and logical accentuation in music. Cook probably right when he said that Meyer's method is a good starting point in music analysis. I think the awareness of musical accentuation in Meyer's analysis is having a close relationship with the basic musical form analysis that generally based on antecedent and consequent. Meyer's analysis would be valuable for Shenkerian sides only if they are not merely learning Meyer's analysis technique but also to understand his theoretical concept of musical style. That is why Meyer mostly is considered in the area of music aesthetic rather than in the technical analysis field where he is strongly criticized.

Regarding its relevance to the Indonesian analytical study of Western music, knowledge of Meyer's approaches that have been discussed in this paper of course offering the expansion of horizon and insight in music analysis as well as musical esthetic studies in Indonesian higher education for music fields. However, it would be more appropriate to be given in further studies such as Masters and Doctors rather than in undergraduate studies.

\section{REFERENCES}

Aulia, M.H; Indrawan, A. 2019. "Penerapan Sistem Komposisi Serial pada "El Polifemo de Oro" untuk Gitar Karya Reginald Smith Brindl", Promusika: Jurnal Pengkajian, Penyajian, Dan Penciptaan Musik, 7(1), 45-58. Retrieved from https: //doi.org/10.24821/promusika.v7i1.3168

Bent, I. 1980. "Analysis" in S. Sadie (Ed.), The New Grove Dictionary of Music and Musicians (Vol. 1, pp. 340-388). Macmillan Publisher Limited.

Bent, I. 1987. Analysis: The New Grove Handbooks in Music. New York: W.W. Norton \& Co.

Brindle, R.S. 1963. El Polifemo de Oro: Quattro Frammenti per Chitarra. Firenze: Aldo Bruzzichelli. 
Brindle, R.S. 1982. El Polifemo de Oro for Solo Guitar (Schott 118). New York; London: Mainz Schott.

Cook, N. 1987. A Guide to Musical Analysis. USA: J.M. Dent.

Cope, D. H. 1984. New Directions in Music. USA: Wm C. Brown Company Publishers.

Forte, A; Gilbert, S.E. 1982. Introduction to Shenkerian Analysis. New York and London: W.W. Norton \& Co.

Fubini, E; Hatwell, M. 1990. The History of Music Aesthetics. London: The Macmillan Press, Ltd.

Geyer, D.L. 2011. "The Pragmatic Theory of Truth as Developed by Peirce, James, and Dewey" (A. Mastronardi \& B. Toizer, Eds.). Retrieved from www.gutenberg.net

https: //www.music.ox.ac.uk/research/ disciplines/psychology-of-music/ Psychology of Music. Retrieved December 1, 2019, from Research/ Disciplines website.

Indrawan, A. 2010. "Kritik terhadap Pendekatan Psikologi Meyer dalam Studi Analisis". Ekspresi: Jurnal Penelitian Dan Penciptaan Seni, 10(1).

Indrawan, A. 2019. "Perjalanan Sang Diatonis: Dari Pythagoras Sampai Multi Media" in Sunarto (Ed.), Musik dalam Perspektif (Pustaka Mu, pp. 181-203). Retrieved from http: //lib.isi.ac.id/

Lamba, L; Ardini, N.W; Darmayuda, IK; Sumerjana, K. 2019. Analisis Lagu Toraja Marendeng Marampa Aransemen Tindoki Band. Journal of Music Science, Technology, and Industry, 2(2), 169-184. Retrieved from https: //doi.org/10.31091/jomsti.v2i2.865

Lerdhal, F; Jackendoff, R. 1996. A Generative Theory of Tonal Music. USA: The MIT Press.

Lewin, D. 1981. Some investigation into Foreground Rhytmic and Metric Patterning. In R (ed. . Browne (Ed.), Music Theory: Special Topics. New York: Academic Press, Inc.

McCarthy, M; Globe, S. 2002. Music Education Philosophy: Changing Times. Music Educators Journal, (SAGE Journals). Retrieved from https: //doi.org/10.2307/3399880

Meyer, L.B. 1956. Emotion and Meaning in Music. Chicago: The University of Chicago Press.

Meyer, L.B. 1957. Meaning in Music and Information Theory. The Journal of Aesthetics and Art Criticism, 15(4), 412. https: //doi.org/10.2307/427154

Meyer, L.B. 1967. Music, The Arts and Ideas; Patterns and Prediction in Twentieth-Century Culture. Chicago: The University of Chicago Press.

Meyer, L.B. 1973. Explaining Music; Essay and Explorations. Berkeley: University of California Press.

Meyer, L. B. 1982. Process and Morphology in the Music of Mozart. Journal of Musicology, 1(1), 67-94. https: //doi.org/10.2307/763638

Meyer, L.B. 1983. Innovation, Choice, and the History of Music. Critical Inquiry, 9(3), 517544. https: //doi.org/10.1086/448215

Meyer, L.B. 1989. Style and Music: Theory, History, and Ideology. Philadelphia: The University of Pensylvania Press. 
Meyer, L.B. 1998. A universe of universals. Journal of Musicology, 16(1), 3-24. https: //doi.org/10.2307/764076

Prier, K.E. 2004. Ilmu Bentuk Musik. Yogyakarta: Pusat Musik Liturgi.

Putra, I.P.A.S.S. 2019. Analisis Komposisi Musik "Kuasa Tanah." Journal of Music Science, Technology, and Industry, 2(1), 49-84. Retrieved from https: //doi.org/10.31091/jomsti.v2i1.604.

Shattuck, K. 2008 (January 2). Leonard B. Meyer, Scholar of Music's Meaning, Is Dead at 89. The New York Times. Retrieved from https: //www.nytimes. com/2008/01/02/arts/02meyer.html?_r=0.

Sparshott, F.E; Cumming, N. 2018 (January 11). Meyer, Leonard B. https: //doi.org/10.1093/gmo/9781561592630.article.18551.

Syahrian, A; Irawan, R; Aryanto, A.S. 2019. Bentuk dan Makna Lagu Ida Sang Sujati Karya I Komang Darmayuda. Journal of Music Science, Technology, and Industry of Music Science, Technology, and Industry, 2(2), 199-218. Retrieved from https: //doi.org/10.31091/jomsti.v2i2.867.

Watanabe, R.T. 1967. Introduction to music research. Englewood Cliffs, New Jersey. Prentice-Hall, Inc. 